Volume 3 Nomor 2, Juli-Desember 2019: hlm. 63-70.

Magister Ilmu Hukum, Fakultas Hukum, Universitas Lampung,

Bandar Lampung, Lampung, Indonesia.

E-ISSN: 2598-3105 P-ISSN: 2723-2581

http://jurnal.fh.unila.ac.id/index.php/cepalo

\title{
ANALYSIS OF REVOCATION OF LAND RIGHTS BY THE GOVERNMENT REVIEWED FROM THE CONCEPT OF LOSS
}

\author{
Natasha Marcella Geovanny \\ Universitas Tarumanagara \\ natashamarcella36@yahoo.com \\ Marchelina Theresia \\ Universitas Tarumanagara \\ marchelinatheresia@gmail.com \\ Devina Felicia Widjaja \\ Universitas Tarumanagara \\ devinawidjaja16@gmail.com
}

\begin{abstract}
The control of land by the state is stated in Article 33 paragraph (3) of the 1945 Constitution of the Republic of Indonesia (UUD 1945). Based on this article, it means that the State has authority over land tenure, this encourages the writing of a journal on the application of social functions and the determination of compensation that occurs in the land sector. This research was conducted because the authors see that there are still many disputes related to the implementation of the social function itself and the application of the determination of compensation as stipulated in the provisions relating to this matter it is caused because the application in real life has not been running optimally. This study aims to find out how the government's authority should be for land tenure and its relation to social functions and the determination of compensation. The location used as a case study is located in Batu Jaya Village, Tangerang City. Data collection is done by interviewing several related parties and also conducting a literature study by finding sources related to government authority over land tenure, the concept of social functions, and the determination of compensation. The results of this study indicate that the government has the power to grant land rights and revoke land rights in the public interest.
\end{abstract}

Keywords: Land, Land Tenure, Public Interest.

How to Cite: Natasha Marcella Geovanny, Marchelina Theresia, Devina Felicia Widjaja, "Analysis of Revocation of Land Rights by the Government Reviewed from the Concept of Loss", Jurnal Cepalo, 3 (2), (2019): 63-70.

DOI: https://doi.org/10.25041/cepalo.v3no2.1845

\section{A. Introduction}

Land is one of the most essential aspects of human needs, etc., as stated in the 1945 Constitution article 33 paragraph (3) states that the State controls the earth, water and natural resources contained therein and used for the maximum possible prosperity of the people, and with the existence of an affirmative article in Law Number 5 of 1960 article 2 paragraph (1) which contains that the earth, water, and space, and all the wealth contained therein is at the highest level controlled by the State as an organization of power all people and land are one of them. With the existence of these two articles, it can be understood that the state controls the land and is given the authority to regulate the use of land in the sense of use, provision, and regulate the provision of land for the benefit of the community. ${ }^{1}$

\footnotetext{
${ }^{1}$ Andi Bustamin Daeng Kunu, “Kedudukan Hak Menguasai Negara Atas Tanah”, Fiat Justitia: Jurnal Ilmu Hukum, Vol. 6 No. 1 ,
} (2012), hlm. 2. 
Based on the context of the Basic Agrarian Law, the concept of land ownership which in this case is the legal relationship with the land which is said to be the right to land is the relationship of ownership and ownership. The land rights have authority which includes ownership rights to land rights that do not have a term such as ownership rights and power to control land rights for a temporary period such as land use rights, land use rights, and use rights. Based on the explanation, there are several authorities in the land rights, including the authority to use, transfer, and guarantee the land they have.

In the ownership or management of land by a person, of course, a right will be guaranteed which guarantees and is recognized by the state. But when the use of land without permission as formulated in article 385 paragraph 4 of the Criminal Code contains that someone who has the same intent, mortgaged, leases land that does not have a certified right, and knows that another person has the power the land will be imprisoned for 4 years and Article 3 and Article 4 of Law Number 51 PRP of 1960 which can be interpreted that the local government can take action to settle the use at any time and order to vacate the land and all goods and people given from her. ${ }^{2}$ As stated in the Government Regulation instead of Law Number 51 of 1960 concerning Prohibition of Use of Land without a Right of Permit or Power of Attorney, which regulates the prohibition of using or using land without the legal permission or legal power. Using land has the meaning of inhabiting, working on and / or touching a piece of land or having buildings or plants that are on the land, and is not questioned about the use of the building used alone or together. According to article 6 paragraph (1) of the Government Regulation instead of Law Number 51 of 1960, anyone who uses land without a proper permit or legal proxy is an act that violates the law and can be subject to criminal penalties.

Like what happened in Batu Jaya Village, there was land given by the local government, on the land four houses were built which were made by residents as rented houses that did not have a valid permit and had to face eviction. The eviction occurred because of the project to expand the Batu Jaya Elementary School area, which is located right next to the building.

The research method that the author uses in preparing this journal is empirical. This research was conducted by taking a location in the village of Batu Jaya, Tangerang City. The author chose the location of research in the village of Batu Jaya, Tangerang City because of the case there, attracting the attention of the writer. Data sources and types of data used by the author in conducting this research include primary data, an empirical study obtained at the research site directly through interview techniques conducted jointly with sources which in this case are homeowners who are in the village of Batu Jaya, Tangerang City. Secondary Data, is data obtained by the author through books, magazines, journals, or internet media sources which are then considered by the author relating to the problem being discussed.

In the field research, the authors conducted direct and open interviews in the form of questions and answers with the resource persons or related parties, which are similar to the problem in this paper so that the data obtained is related to what will be written. Data obtained from primary data and secondary data will be processed and analyzed qualitatively, and the data will later be described. Qualitative analysis is a qualitative analysis of numerical data and verbal data descriptively by describing the real condition of the object to be discussed using a formal juridical approach and based on the doctrinal concept of law. The qualitative information is described by words or sentences separated by categories to get conclusions.

\section{B. Discussion}

\section{Analysis of State Power in Granting and Revoking Land Rights to Rightsholders}

State land is land that is directly controlled by the state. The word "directly controlled" means that there is no other party involved in the land. The term state land originated in the Dutch East Indies era, and it is by the concept of the Dutch government which states that any land that does not have proof of ownership will become the property of the state.

Based on the Basic Agrarian Law (UUPA) article 2 paragraph (1) which explains that all land and natural resources are controlled by the State. If on land no one has the rights to the land, the state will be the ruler of the land. But if on a land there is a base of rights, the owner of the land who has the base of the right. ${ }^{3}$ The state's authority over the control of land that is owned by someone with a right is limited by the content of that right, which means that to what extent the state can give power to people who have the right

\footnotetext{
${ }^{2}$ Law No. 51 of 1960 concerning Prohibition of Use of Land without a Rightful Permit or Proxy.

${ }^{3}$ Ibid.
} 
to exercise their rights, that is where the limit of the power of that state is ${ }^{4}$ However, no interpretation specifically explains the meaning of "controlled by the state" either in the body or in the explanation of the 1945 Constitution. It can be seen here that there has been a change, land is no longer owned by the state but only controlled by the state.

In the explanation that it is seen that the state has the authority to regulate the use of land, it is included in giving rights to the land to citizens for their people to gain prosperity. In the case, the author discussed that the state (local government) gave Abdul Patah a plot of land to be used to build a house for his residence with his family. This does not violate the provisions stipulated in the Basic Agrarian Law (UUPA) article 4 paragraph (1), regarding the right to grant land and gives authority to the recipient of the right to use it which is regulated in the Basic Agrarian Law (UUPA) ) article 4 paragraph (2), the existing system in the Basic Agrarian Law (LoGA) stipulates that land rights are open, which means it is possible to add to the kinds of rights that can be added to the law, adding the various types of rights occur because of the dynamics of growth. ${ }^{5}$

The use of land must be by the conditions of its nature and rights so that it can provide interests and prosperity for all Indonesian people and for the country. The interests referred to above must also be in a balanced state. ${ }^{6}$ As explained by the presentation that in the implementation of the land rights must be followed by evidence of rights that have been granted by the state, where the recipient of these rights must track their use as determined by the government. In the case of land acquisition by the government due to the public interest the community can use the land in accordance with the provisions of ownership rights, land use rights, building rights and use rights listed in Government Regulation No. 40 of 1996, which means that the community can manage the land they have acquired for their interests as long as it complies with existing provisions. In the case of the writer, it can be seen that the rights granted by the government to the recipient of the right are the usage rights. ${ }^{7}$

According to Soedikno Mertokusumo the right to use is one of the scopes of Agrarian law because the substance of the regulation is regulated in the LoGA. ${ }^{8}$ Another definition of usage rights is contained in Article 41 of Law Number 5 of 1960 concerning Basic Regulations on Agrarian Principles which read: "The right to use and / or collect the results of land that is directly controlled by the State or land owned by others, which gives authority and obligation determined in the decision to grant it by the authorized authority to give it or in an agreement with the owner of the land, which is not a lease agreement or land management agreement, everything as long as it does not conflict with the soul and the provisions of the basic agrarian law".

According to Article 41 of Law Number 5 of 1960 concerning Basic Regulations on Agrarian Principles, the Right to Use is the right to use and collect the results of land that is directly controlled by the State or land owned by someone else. In the explanation of the article, it can be seen that the recipient of the right only has the right to use and collect results. In the case of the author who was careful that the recipient of the right instead used the building for rent as a place of collision and violated Government Regulation No. 40 of 1996 because the recipient of the right can only use the land by the rights granted by the government. ${ }^{9}$ Land acquisition activities for the sake of development are theoretically based on certain principles or principles and are divided into two subsystems:

a. Land acquisition by the government due to public interest;

b. Land acquisition by the government is not due to the public interest.

The public interest is the interest of the nation and the state and the common interests of the people, by paying attention in terms of social, political, psychological, and national defence and security based on the principles of national development by paying attention to national resilience and archipelago insight. ${ }^{10}$ The government has a normative authority to regulate the land sector, therefore specifically for the implementation of growth in the public interest according to Law Number 5 of 1960 concerning Basic Regulations on Agrarian Principles, State Gazette Number 104 of 1960. Article 18 contains the interests

\footnotetext{
${ }^{4}$ A.P. Parlindungan, Komentar Atas Undang-Undang Pokok Agraria, Bandung: PI Mandar Maju, (1991), hlm. 39.

${ }^{5}$ Urip Santoso, "Pengaturan Hak Pengelola”, Jurnal Media Fakultas Hukum UMY Yogyakarta, Vol. 15 No.1, (2008), hlm. 142.

${ }^{6}$ Kartini Muljadi dan Gunawan W, Hak-Hak Atas Tanah Seri Hukum Harta Kekayaan, Jakarta: Prenada Media, (2004), hlm. 24.

${ }^{7}$ Subekti Dan R. Tjitrosoedibio, Kamus Hukum, Jakarta: Pradnya Paramita, (1983), hlm. 12.

${ }^{8}$ Soedikno Mertokusumo, Hukum dan Politik Agraria, Jakarta: Universitas Terbuka Karunika, (1988), hlm. 1-2.

${ }^{9}$ Oloan Sitorus, Konsolidasi Tanah, Tata Ruang, dan Ketahanan Nasional, Yogyakarta: STPN Press, (2015), hlm. 5.

${ }^{10}$ John Salindeho, Masalah Tanah Dalam Pembangunan, Cetakan Kedua, Jakarta: Sinar Grafika, (1988), hlm. 40.
} 
general belonging to the interests of the Nation and the State and the common interests of the people themselves.

As the author has explained above that the government can take the rights to the land given to the recipient of the right when the land is for social functions such as what is stated in Law Number 5 of 1960 concerning Basic Regulations on Agrarian Principles (UUPA), on Article 1 paragraph (1) states that: "all land within the territory of the State of Indonesia is the common land of all Indonesian people" ${ }^{11}$ which can be understood that all land within the territory of the Republic of Indonesia is a natural wealth owned by all Indonesian people in order to obtain a prosperity that has been aspired.

In reaching the aspirations of natural wealth for the prosperity of the people, an instrument will emerge in order to achieve what it aspires to, one of which is land acquisition for public use, in article 1 paragraph 2 of Law Number 2 of $2012^{12}$ concerning Land Procurement Development in the Public Interest that the acquisition of a land can be carried out in the public interest, and can also be seen in article 10 letter $\mathrm{p}$ of Law Number 2 of 2012 concerning Land Procurement for Development in the Public Interest that educational facilities (schools) are one of the aspects that take precedence in land acquisition that can be carried out by the government and in article 11 it is stated that the government must carry out the land acquisition up to the local government, but in this Law the writer feels there must be a voluntary feeling from the party receiving the land rights to give his land to release his land for the sake of sake In general.

Whereas in Law Number 20 of 1961 which states that the revocation of rights to a land for public purposes, the word revocation reflects that the land can be taken by force for public purposes, ${ }^{13}$ but it must also be considered whether modern law in carrying out revocation of rights Whether the land is already in force or not, when the government releases and revokes the rights to a land, it must be carried out together with the recipient of the land rights. Because in practice there is land acquisition and revocation of rights to a land for the public interest, even ignoring those whose rights have been revoked, this is contrary to modern law in force in Indonesia which must achieve justice in all aspects of community life. This matter which must be avoided by the government to achieve the public interest which is fulfilled also does not cause harm to those whose land rights are revoked. In the case that the author discussed, it can be seen that the government revoked the right to a land for the expansion of the school area in accordance with article 1 paragraph 2, Article 10 letter p of Law Number 2 of 2012 and also Law Number 20 of 1961 which discussed land acquisition for public use namely the school, but the government has not been able to carry out these efforts coupled with a positive legal concept because the parties to the recipient of land rights feel disadvantaged due to revoking the rights not included with proper compensation.

\section{Concepts of Social Functions in the LoGA based on Modern Legal Concepts and Determination of Compensation}

Based on article 6 of Law No. 5 of 1960 concerning Basic Agrarian Affairs has stressed that all land rights have a social function. According to Leon Duguit, social function is no subjective right, and there is only social function. From this it means that in the use of land rights only pay attention to social or community interests. In this case, it can be seen that the intended social or community interest is the Batu Jaya SDN area expansion project. His thinking is based on denial of the existence of individual rights because there is only a social function. His opinion about social functions is in line with the opinion expressed by Rudolf von Jhering ${ }^{14}$ regarding collective happiness as the goal of the existence of law, not individual happiness. Individual happiness itself can be achieved if social happiness has been achieved first. That the explanation emphasizes that the use of land controlled by the state should be used for the benefit of many people, not just individuals or groups.

Furthermore, according to article 6 of the BAL which contains that all land has a social interest that is to put the common interests first rather than personal or group interests. The existence of the principle of the social function of rights to a parcel of land in the land law becomes the fundamental foundation for the realization of land that is beneficial for the greatest prosperity of the people in the welfare state. ${ }^{15}$

\footnotetext{
11 Triana Rejekiningsih, "Asas Fungsi Sosial Hak Atas Tanah Pada Negara Hukum (Suatu Tinjauan dari Teori, Yuridis dan Penerapannya di Indonesia”, Yustisia Jurnal Hukum, Vol.5 No.2, (2016), hlm. 299.

${ }^{12}$ Law No. 2 of 2012 concerning Land Procurement for Development in the Public Interest.

${ }^{13}$ Law No. 20 of 1961 concerning the Revocation of Rights to the Land and the Items above it.

${ }^{14}$ Darji Darmodiharjo \& Shidarta, Pokok-Pokok Filsafat Hukum; Apa dan Bagaimana Filsafat Hukum Indonesia, Jakarta: Gramedia Pustaka Utama, (2006), hlm. 121.

${ }^{15}$ Ibid., 300
} 
Welfare that can be interpreted in the case discussed by the author in the development of the school area to increase the comfort and facilities of students. ${ }^{16}$ The land management system is a matter for the government. Therefore the social function of land rights can be formulated in several forms such as policy, regulation, regulation and control, and service. In the context of carrying out social missions, the government considers the availability of land, in order to meet the needs of parties who have an interest or stakeholders, certainty and legal protection for holders of land rights, that by fulfilling social functions in the case discussed by the author will create comfort and the availability of facilities to meet the educational needs of Batu Jaya Elementary School students. It is hoped that the expansion of the area for these schools can have a positive impact on the world of education in the future which is by the purpose of the social function itself, which is for the welfare of the community, not just the welfare of individuals.

Although the concept of land management which has a social function has been stated in the Basic Agrarian Law, the social function of land rights cannot be clearly explained in the form of policies, regulation, control and supervision, and services in the field of land, due to the social function meant to still collide with the public interest of the injured community. Therefore a comprehensive study of policy development related to the social function of land rights is needed. In the revocation of land rights accompanied by evictions in the public interest it is fulfilled but when viewed from the side of the evicted victim, it is very detrimental because the evicted victim loses his livelihood and also the rented tenant suffers a loss because he has paid the cost but cannot occupy the rent which is where it was caused by eviction.

Based on the explanation above, the author agrees that social functions should be developed to be inherent in all aspects of agrarian rights so that not only land rights have social functions, but also other agrarian rights such as earth, water, and space and the wealth contained therein has a social function. It is also hoped that the formation of policies in the field of land especially regarding the policy of land social functions in order to be able to make a real contribution to the welfare of the general public so that they have the opportunity to utilize land optimally and it can be seen that the government has the authority to revoke rights for social interests such as those happened when the Tangerang City government wanted to revoke the rights to a land from Abdul Patah's family because the land they occupied as a residence would be used for school expansion and it was included in social interests or social functions.

The social function of land rights that has been affirmed above is in line with the basic norms (ground norm) in Indonesia which have ideals regarding "general welfare and social justice" as stated in Article 33 of the 1945 Constitution which states that the State controls the earth, water and wealth the nature contained therein and used for the greatest prosperity of the people. To realise the obligations of the state concerning the right to control the state for the greatest prosperity of the people, namely:

a. All forms of water and earth benefits as well as anything in them must be for the prosperity and welfare of the community;

b. Protect and guarantee people's rights contained in or on the earth, water, and various natural resources whose results can be directly enjoyed by the people;

c. Prevent all treatment from any party, which can cause people not to get their rights. ${ }^{17}$

The use and arrangement of land by the state is intended to be utilized to realize social justice for all Indonesian people. The control of land by the state needs to pay attention to the interests of the broader community so as not to cause problems and by the intended use. ${ }^{18}$ In fact in Article 33 of the 1945 Constitution the words of the social function are not explicitly stated, but it can be interpreted that the social function, rather than the right of primaries, has the understanding that such property rights must not be allowed to harm the interests of the community.

In obtaining or obtaining land rights, it is not absolute but has a social function as regulated in article 6 of the Basic Agrarian Law (UUPA), ${ }^{19}$ such as in the expansion of the SDN Batu Jaya area which is a social interest. Then through the local village sub-district was given some money to compensate for the eviction carried out on several houses on the land which was rejected by the landowner because it was considered unofficial and not by the provisions of compensation should be. It is regulated in Article 1 point 2 of Law

\footnotetext{
${ }^{16}$ Agus Surono, Fungsi Sosial Tanah, Jakarta: Fakultas Hukum Universitas Al-Azhar Indonesia, (2013), hlm.59.

${ }^{17}$ Bagir Manan, Beberapa Catatan Atas Rancangan Undang-Undang Tentang Minyak dan Gas Bumi, Bandung: Fakultas Hukum Universitas Padjajaran, (1999), hlm. 1-2.

${ }^{18}$ Irene Eka Sihombing, Segi-Segi Hukum Tanah Nasional dalam Pengadaan Tanah Untuk Pembangunan, Jakarta: Universitas Trisakti, (2009), hlm. 12

${ }^{19}$ Eman, "Pengadaan Tanah Bagi Pelaksanaan Pembangunan Untuk Kepentingan Umum", Jurnal Yurisdiksi Fakultas Hukum Universitas Airlangga Surabaya, Vol. 23 No.1, (2008), hlm.52
} 
Number 2 of 2012 concerning land acquisition for development in the public interest. The legal basis related to the acquisition of land for public purposes in Indonesia refers to the provisions in Article 18 of the BAL which reads: "For the public interest, including the interests of the nation and state and the common interests of the people, land rights can be revoked, by compensating that is feasible and in the manner regulated by Law ".

According to Government Regulation No. 71 of 2012, it is explained that compensation is fair and appropriate compensation for the parties entitled to the land acquisition process. ${ }^{20}$ The party entitled is the party in power to control or own the object of land acquisition. Therefore, land has a social function to guarantee its binding on individual rights that are binding to provide compensation for land used for public purposes, which in this case is an expansion of the area for the Batu Jaya SDN development project.

The definition of compensation for the land itself has not been widely explained either in the Act or Government Regulation in terms of regulating the Act itself. However, based on the explanation above regarding the definition of compensation itself, it can be explained that the government should replace the land compensation by all parties. The issue of compensation is one of the most important things in the land acquisition process. The determination of the amount of payment in the land sector is carried out by the Chairperson of the Land Acquisition Implementation based on the results of the appraisal or public appraisal services assessment. ${ }^{21}$ Compensation is given to the right party which is based on the results of the evaluation determined in the deliberations on determining compensation and / or decisions of the District Court or Supreme Court. The party entitled to receive the compensation is responsible for the truth and validity of the evidence of ownership or ownership submitted. If there is a violation of that matter, criminal sanctions will be imposed which are by applicable laws and regulations.

The problems that arise in land acquisition activities are more caused by statutory provisions in the land sector that do not protect holders of land rights. ${ }^{22}$ Especially in matters relating to compensation aspects, the existing regulations have not yet concretely guaranteed the lives of the holders of land rights to obtain a better experience than before. The implementation shows that there is a process of impoverishment of the holders of land rights in every development project intended for the public interest. Real evidence can be seen in forced evictions of buildings owned by holders of land use rights in the village of Batu Jaya, for which they did not receive the appropriate compensation and they should have received forcible evictions they experienced. It is due to the actual regulation and implementation in the field which is still far from the ideal both sociologically, juridically, and philosophically. Which is not by Government Regulation No. 71 of 2012 which contains that compensation provided to the parties entitled to it should be fair and reasonable, but in this case the compensation made is considered to be inappropriate and fair.

First determination and method of calculating compensation/land price that refers to the real or actual value by taking into account and considering the Sales Value of Tax Objects (NJOP), it has been included in Presidential Regulation No. 36/2005. The Presidential Regulation does not take into account compensation for non-physical factors.

Forced eviction can be understood as the process of involuntary removal of individuals, families, and communities from the house or land occupied temporarily or permanently without any provision or access to proper legal procedures or necessary protection. In the process of eviction from the beginning of the eviction until after the eviction, it must be by existing regulations, but the reality that occurred in the field in the preeviction stage in the case of dispute in Batu Jaya village. When the residents asked for this problem to be mediated first, it was ignored by the government. When the residents reported about the forced eviction to be carried out by the local government, in the evening the residents received a letter from the Satpol PP who would conduct the eviction the next day.

The government action that should be done in this case is to protect the rights of its people, but in reality, there is no good faith from the government itself in protecting the rights of its people. As can be seen in the explanation above, people want to use peaceful methods such as by conducting mediation. The community asked the government to show the basis for the ownership of the land, which in this case meant that SDN Batu Jaya as the party claiming to have the rights to the land, could not show the basis for the rights to the

\footnotetext{
${ }^{20}$ Moh Fahmi Baharudin, "Mekanisme Pengadaan dan Konsinyasi Ganti Rugi Tanah Oleh Pemerintah Terkait dengan Pembangunan Jalan Umum", Skripsi Fakultas Syariah dan Hukum Universitas Islam Negeri Syarif Hidayatullah, Jakarta, (2015).

${ }^{21}$ Rahayu Subekti, "Kebijakan Pemberian Ganti Kerugian dalam Pengadaan Tanah bagi Pembangunan untuk Kepentingan Umum", Yustisia, Vol. 5 No. 2, (2016), hlm. 384.

${ }^{22}$ Dekie GG Satenda, "Ganti Rugi dalam Pengadaan Tanah untuk Kepentingan Umum”, Jurnal Morality, Vol. 2 No. 2, (2015), hlm.6.
} 
land. In this case, it can be seen that both parties are in a position of not being able to show the basis for the right of ownership of the land, therefore the eviction process that occurs should not be carried out until either party can show the legal basis for the ownership of the land or the existence of decisions that have been determined by the court.

After the eviction set by the government, the affected people should receive compensation. Compensation is replacing those given in physical or non-physical form as a result of land acquisition for those who have building land, plants and objects that are above the land to provide a better life. This can be seen from the level of social, economic life before being affected by the land acquisition project. The form of compensation to be obtained can be in the form of money, replacement land or resettlement, or a combination of these forms of compensation, and this can be discussed by the parties concerned. ${ }^{23}$ Land acquisition referred to above is land acquisition, which can be divided into two, namely land acquisition for government interests, namely public interest and private interest. ${ }^{24}$ In the case of compensation. After the forced eviction carried out by Satpol PP on the building of the house, the parties related to the eviction did not show any good intentions in this case in the form of compensation for the building of the forced evicted house. Camat as sub-district leader then gave money of Rp. 10,000,000.00 to the evicted homeowners to be distributed equally (for four houses). But in reality the giving of the money that was addressed as compensation for the eviction did not have a letter or a valid basis which caused a rejection by the owners of the house itself. Even though certain parties cannot provide compensation unilaterally, because only the governor and the court can impose an execution ${ }^{25}$, the local government conducts forced evictions of the heirs without waiting for the final decision of the court regarding the case.

Various types of rights, the rights used in this matter are the Right to Use in compensation land for evictions made on the previous land. Usage rights can be defined as the rights obtained by a person to utilize the land or house lent by an institution or the state or individuals. Use rights can be granted on land with the status:

a. State land

b. Land management rights

c. Property rights

\section{Conclusion}

The land has a vital and integral role in human life, and it is because humans live and carry out various activities on the land. But along with time disputes over land tenure are also often found in Indonesia, one of which is regarding the application of social functions and the determination of compensation. The state has authority in the right to control land, this is stated in the Basic Agrarian Law (UUPA) article 2 paragraph (1). The government, in this case exercising this authority, is one of them by giving a right to land which is stated in Article 4 paragraph (1) of the LoGA, but the government can also revoke the right to land which is done to realize public welfare which in accordance with Article 10 letter p of Law Number 2 Year 2012 and even Law Number 20 Year 1961 which discusses land acquisition for public purposes. The application of social functions here is also regulated in Article 6 of the LoGA which is expected that the actual actions of this social function can be maximized so that all parties can feel the welfare that they should. Based on the provisions, one of which regulates the compensation in Government Regulation No. 71 of 2012, the author expects that the implementation of compensation that often occurs due to the acquisition of land in the public interest to be optimized because in reality the compensation process that happens is still not optimal. Which is very detrimental to the parties entitled to compensation.

\footnotetext{
${ }^{23}$ Presidential Regulation No 65 Year 2006 Jo Presidential Regulation No. 36 of 2005.

${ }^{24}$ Bernhard Limbong, Pengadaan Tanah Untuk Pembangunan, Jakarta: Rafi Maju Mandiri, (2011), hlm.129.

${ }^{25} \mathrm{https}$ //www.bantuanhukum.or.id/web/tolak-penggusuran-warga-kapuk-poglar-mengadu-ke-komnas-ham/ diakses pada tanggal 11 September 2019 pukul 21.58 WIB.
} 


\section{Bibliography}

\section{A. Book}

A.P. Parlindungan. (1991). Komentar Atas Undang-Undang Pokok Agraria. Bandung: PI Mandar Maju

Darmodiharjo, Darji dan Shidarta. (2006). Pokok-Pokok Filsafat Hukum; Apa dan Bagaimana Filsafat Hukum Indonesia. Jakarta: Gramedia Pustaka Utama.

Harsono, Boedi. (2013). Hukum Agraria Indonesia (Sejarah Pembentukan Undang-Undang Pokok Agraria, Isi dan Pelaksanaanya), Jakarta: Universitas Trisakti.

Limbong, Bernhard. (2011). Pengadaan Tanah Untuk Pembangunan. Jakarta: CV Rafi Maju Mandiri.

Manan, Bagir.(1999). Beberapa Catatan Atas Rancangan Undang-Undang Tentang $\quad$ Minyak Dan Gas Bumi. Bandung: Fakultas Hukum Universitas Padjajaran.

Mertokusumo, Soedikno. (1988). Hukum dan Politik Agraria. Jakarta: Universitas Terbuka Karunika.

Muljadi, Kartini dan Gunawan W. (2004). Hak-Hak Atas Tanah Seri Hukum Harta Kekayaan. Jakarta: Prenada Media

Nasional. Yogyakarta: STPN Press.

Salindeho, John. (2008).Masalah Tanah Dalam Pembangunan, Cetakan Kedua. Jakarta: Sinar Grafika

Sihombing,Irene Eka.(2009). Segi-Segi Hukum Tanah Nasional Dalam Pengadaan Tanah Untuk Pembangunan. Jakarta: Universitas Trisakti.

Sitorus, Oloan.(2015).Konsolidasi Tanah, Tata Ruang, dan Ketahanan

Subekti Dan R. Tjitrosoedibio. (1983). Kamus Hukum. Jakarta: Pradnya Paramita.

Surono, Agus. (2013). Fungsi Sosial Tanah. Jakarta: Fakultas Hukum Universitas Al-Azhar Indonesia.

\section{B. Journal and Article}

Andi Bustamin Daeng Kanu, "Kedudukan Hak Menguasai Negara Atas Tanah", Fiat Justisia Jurnal Ilmu Hukum, Vol. 6 No. 1, (2012).

Dekie GG Satenda, "Ganti Rugi dalam Pengadaan Tanah untuk Kepentingan Umum”, Jurnal Morality, Vol. 2, No. 2, (2015).

Eman, "Pengadaan Tanah Bagi Pelaksanaan Pembangunan Untuk Kepentingan Umum", Jurnal Yurisdiksi Fakultas Hukum Universitas Airlangga Surabaya, Vol. 23 No.1, (2008).

Moh Fahmi Baharudin, "Mekanisme Pengadaan dan Konsinyasi Ganti Rugi Tanah Oleh Pemerintah Terkait dengan Pembangunan Jalan Umum” Skripsi Fakultas Syariah dan Hukum Universitas Islam Negeri Syarif Hidayatullah Jakarta, (2015).

Rahayu Subekti, "Kebijakan Pemberian Ganti Kerugian dalam Pengadaan Tanah Bagi Pembangunan untuk Kepentingan Umum”, Yustisia, Vol. 5 No. 2, (2016).

Triana Rejekiningsih, "Asas Fungsi Sosial Hak Atas Tanah Pada Negara Hukum (Suatu Tinjauan dari Teori, Yuridis dan Penerapannya di Indonesia", Yustisia Jurnal Hukum, Vol.5 No.2, (2016).

Urip Santoso, "Pengaturan Hak Pengelola", Jurnal Media Fakultas Hukum UMY Yogyakarta, Vol. 15 No.1, (2008).

\section{Legislations}

Law No. 2 of 2012 concerning Land Procurement for Development in the Public Interest.

Law No. 20 of 1961 concerning the Revocation of Rights to the Land and the Items above it.

Law No. 5 of 1960 concerning Basic Agrarian Affairs (UUPA).

Law No. 51 of 1960 concerning Prohibition of Use of Land without a Rightful Permit or Proxy.

Presidential Regulation No 65 Year 2006 Jo Presidential Regulation No. 36 of 2005.

\section{Internet}

Bantuan hukum 27 Januari 2018. "Tolak penggusuran kapuk polar mengadu ke komnas HAM" https://www.bantuanhukum.or.id/web/tolak-penggusuran- warga-kapuk-poglar-mengadu-ke-komnasham/ diakses pada tanggal 11 September 2019 pukul 21.58 WIB 